NBER WORKING PAPER SERIES

\author{
TAX INTEGRATION IN THE U.S.: A GENERAL \\ EQUIIIBRIUM APPROACH \\ Don Fullerton \\ A. Thomas King \\ John B. Shoven \\ John Whalley \\ Working Paper No. $\underline{37 R}$
}

NATIONAL BUREAU OF ECONOMIC RESEARCH

1050 Massachusetts Avenue

Cambridge MA 02138

March 1980

The authors are grateful for financial support from the Office of Tax Analysis, U.S. Treasury Department. Development of the Theoretical model structure has been supported through NSF Grant \#SOC-78-07417. This paper has benefited from comments by George Borts, Peter Diamond, Harvey Galper, Robert Haveman, Jon Kesselman, Nicholas Kiefer, Hudson Milner, Franco Modigliani and an anonymous referee. The research reported here is part of the NBER's research program in Taxation, and Finance, and the Bureau's special project on Capital Formation. Any opinions expressed are those of the authors and not those of the National Bureau of Economic Research. 
Static and Dynamic Resource Allocation Effects of Corporate and Personal Tax Integration in the U.S.: A General Equilibrium Approach

by

Don Fullerton, Princeton University A. Thomas King, Federal Home Loan Bank Board John B. Shoven, Stanford University John Whalley, University of Western Ontario

\title{
SUMMARY
}

This paper presents estimates of static and dynamic general equilibrium resource allocation effects for four alternative plans for corporate and personal income tax integration in the U.S. A medium-scale numerical general equilibrium model is used which integrates the U.S. tax system with consumer demand behavior by household and producer behavior by industry.

Results indicate that total integration of personal and corporate taxes would yield an annual static efficiency gain of around $\$ 4$ billion (1973 dollars). Partial integration plans yield less. Dynamic effects are larger, and our analysis indicates that full integration may yield gains whose present value is as large as $\$ 400$ billion or $0.8 \%$ of the discounted present value of the GNP stream to the U.S. economy after correction for population growth. Plans differ in their distributional impacts, although these findings depend on the nature of replacement taxes used to preserve government revenues. The size of dynamic resource allocation effects are sensitive to the choice of the replacement tax, while static gains are reasonably robust.

\author{
Address inquiries to: \\ Professor John B. Shoven \\ Department of Economics \\ Fourth Floor, Encina Hall \\ Stanford University \\ Stanford, California 94305
}

(415) 497-4108 
This paper presents estimates of static and dynamic general equilibrlum resource allocation effects for four alternative plans for corporate and personal income tax integration in the U.S. A medium-scale numerical general equilibrium model is used which integrates the U.S. tax system with consumer demand behavior by household and producer behavior by industry.

Results indicate that total integration of personal and corporate taxes would yield an annual static efficiency gain of around $\$ 6$ billion (1973 dollars). Partial integration plans yield less. Dynamic effects are larger, and our analysis indicates that full integration may yield gains whose present value is as large as $\$ 400$ billion or $1.0 \%$ of the discounted present value of the GNP stream to the U.S. economy after correction for population growth. Plans differ in their distributional impacts, although these findings depend on the nature of replacement taxes used to preserve govemment revenues. The size of dynamic resource allocation effects are sensitive to the choice of the replacement tax, while static gains are reasonably robust.

\section{The Taxation of Corporate Income}

A corporate tax which operates separately from the personal income tax is widely acknowledged to lead to a number of problems. It creates a "double" taxation of corporate income. Dividends are paid out of net of corporate tax profits and are further taxed under the personal Income tax. Retained earnings, to the extent they are capitalized in higher share values, are also taxed twice, although only fractionally 
and on a deferred basis by the personal income tax. This double taxation may reduce overall rates of return and adversely affect capital accumulation. A second problem is often referred to as the "lock-in" effect. The efficiency of capital markets is impaired due to the deferral advantage given to retained eamings; firms can reinvest retained earnings in projects with a low yield and thelr shareholders can still earn a higher net of tax return than if the funds were distributed as dividends and reinvested elsewhere. Thirdly, since only equity returns are subject to corporate taxes, there is a bias towards debt finance, potentially distorting corporate financial policies. Finally, the corporate tax introduces higher effective tax rates in some industries than others, due to special provisions in the corporate tax law and to the varying degrees to which industries are incorporated. These tax rate differentials further disrupt an efficient allocation of capital. ${ }^{1}$ Integration plans seek to remove or mitigate these features by linking personal income tax liabilities of stockholders (either on dividends or on all earnings) to the corporate tax liabilities of the firms.

A variety of plans have been proposed over the years, but these typically move only part way to a full integration of personal and corporate taxation. The common objective of all these tax integration plans is to improve the efficiency of the economy through beneficial resource reallocation in both a static and a dynamic sense. In this paper four corporate tax integration altematives are considered, each differing in the extent to which they remove the undesirable features of the present corporate income tax mentioned above. 
3

Plan 1: Total Integration: Under this altemative the corporate income tax is eliminated, and the personal income tax is modifled to tax total shareholder eamings rather than just dividends. When capital gains are realized, the tax basis is set at the orfginal purchase price plus the retained eamings cumulated during the holding period. This last feature avolds a double tax on retained earnings capltalized in higher stock prices. However, if the basis is not re-set for inflation, the base for capital gains tax will include pure nominal appreclation. This amounts to a capital wealth levy. We evaluate this partnership Integration plan with and without inflation indexation of capital gains. These total integration plans are the most compehensive we consider and contain modifications to the income tax which, if they had originally been made, would have dispensed with the need for a separate corporate tax. Industrial distortions through the corporate tax are removed as is the corporate tax distortion of intertemporal consumption choice. Plan 2: Dividend Deduction from Corporate Income Tax Base: This approach simply removes the "double" taxation of dividends by making them deductible from taxable corporate income. Capltal gains taxation of Individuals is unaltered, and the corporate income tax is effectively converted into a tax on retalned earnings only. If current differences in-retention policies by industry remain, then some industrial discrimination would continue within the corporate tax.

Plan 3: Dividend Deduction from Personal Income Tax Base: An alternative way of removing "double" taxation of dividends is to allow a dividend deduction from the personal income tax rather than from the corporate income tax. Capital gains taxation is again unaltered. Under. 
this plan, all corporate earnings are taxed at the corporate tax rate, and none are taxed at the personal income tax rate. As with Plan 2, under different retention policies by industry, some industrlal discrimInation will remain under the corporate tax.

Plan 4: Dividend "Gross UP": This was the plan most actively discussed in the U.S. tax reform debate during 1977. It seeks to reduce rather than remove the double taxation of dividends. Part of the income tax paid by corporations is given as an income tax credit to stockholders when dividends are distributed. ${ }^{2}$ The credit is taxable, hence the description "gross up." Because of the partial nature of the credit, none of the distortions listed above can be wholly removed.

\section{A General Equilibrium Model of the U.S. Economy and Tax System}

The implementation of an integration plan results in changes In all relative prices in the economy due to the realignment of industry tax rates; both short and long-rum equilibrium quantities will also change. Intertemporal decisions will be re-evaluated with a changed rate of return to capital, and the division of time between labor and leisure will be altered. The relative positions of groups within the household sector will change, and therefore a complete evaluation of integration plans should incorporate the interacting nature of the efficlency and distributional effects involved. While a new postintegration tax system may involve uniform tax rates and may be easy to evaluate, the existing tax system is nonuniform. Implementation of any corporate tax integration plan will result in a new set of effective tax 
rates on capital income by industry and on personal income by consumer group; and all equilibrium prices and quantities can be expected to vary; the direct effects intended from an integration plan can be offset or reinforced by induced changes in economic behavior.

Because these induced effects are multiple, nonmarginal, and interlinking, general equilibrium analysis is a natural technique to use in evaluating the combination of distributional and efficlency changes. A medium-size general equilibrium model of the U.S. economy and tax system, estimated using 1973 data, is used to analyze the four corporate and personal income tax integration plans. It combines a treatment of the U.S. tax system with competitive consumer and producer behavior. Equilibrium prices and quantities are determined under each integration plan, and the effects of altemative taxation regimes are evaluated. The model possesses a capability for analyzing the impacts of many different tax proposals concerning not only corporate taxes, but also, income, social security, sales, property and other taxes. It incorporates a labor-leisure choice, savings and investment, foreign trade, and government purchase policies. The full range of taxes currently operating in the U.S. are incorporated into the model. Both single-period and multi-period behavior can be considered. In dynamic analyses, a sequence of single-period equilibria is computed, with capital stocks and labor supply changing over time. A labor force growth rate of approximately 2.75 percent per year in efficiency units is used. The precise number is chosen so as to guarantee that the U.S. economy is on an assumed 
balanced growth path in terms of the 1973 data we use. Savings decisions in each period are based on myopic expectations on the rate of retum to capital; only in a steady state are these expectations correct. Nineteen producer good Industries, 16 consumer expenditure 1tems, and 12 consumer types classifled by income range are identified and shown in Table 1. These dimensions are governed by a trade-off between model complexity, data 'availability, and computational expense. Capital and labor services are the primary factor inputs used by industry, and these are owned by consumer groups in different proportions. These two factors are mobile between industries, and their use is dictated by the zero profit conditions of perfectly competitive markets. ${ }^{3}$ Over time the capital service endowment can grow through investment, and the labor service endowment changes through labor force growth. A labor-leisure choice for households also enters the model. More details on the structure and specification of the model and its data are given in Fullerton, King, Shoven, and Whalley (1979).

\section{A Data Sources and Procedures}

The model requires the assembly of a comprehensive and consistent microeconomic data set. Such a data set has not been constructed before for the U.S., but is essential for general equilibrium analysis of taxation policy. ${ }^{4}$ This data set provides information on factor use by Industry (and taxes paid for these), intermediate use of products, outputs of both producer and consumer goods, purchases of consumer goods by household types, incomes by source and by household type, income taxes paid, and several other items such as business investment and foreign. trade. The complete 1973 data set used to calibrate the model is derived 
TABLE 1

Classification of Industries, Consumer Expenditures, and Consumer Groups in the Model

Industries

1. Agriculture, Forestry, and Fisheries

2. Mining

3. Crude Petroleum and Gas

4. Contract Construction

5. Food and Tobacco

6. Textiles, Apparel, Leather Products

7. Paper and Printing

8. Petroleum Refining

9. Chemicals and Rubber

10. Lumber, Furniture, Stone

11. Metals, Machinery, Miscellaneous Manufacturing

12. Transportation Equipment

13. Motor Vehicles

14. Transportation, Communications, and Utilities

15. Trade

16. Finance and Insurance

17. Real Estate

18. Services

19. Government Enterprise

\section{Consumer Expenditures}

1. Food

2. Alcohol ic Beverages

3. Tobacco

4. Utilities

5. Housing

6. Furnishings

7. Appliances

8. Clothing and Jewlery

9. Transportation

10. Motor Vehicles, Tires, and Auto Repair

11. Services

12. Financial Services

13. Reading, Recreation, misc.

14. Nondurable-Nonfood Household Items

15. Gasoline and Other Fuels

16. Savings

Consumer Groups

(Households classified by \$thousands of 1973 gross income)
1. $0-3$
2. $3-4$
5. 6-7
6. $7-8$
3. $4-5$
7. $8-10$
4. $5-6$
8. $10-12$
9. 12-15
10. $15-20$
11. $20-25$
12. $25+$ 
from five major sources including the July, 1976 Survey of Current Business, unpublished worksheets of the U.S. Commerce Department's National Income Division, the Commerce Department's Bureau of Economic Analysis Input/Output tables, the U.S. Labor Department's 1973 Consumer Expenditure Survey, and the U.S. Treasury Department's merged tax file.

Inconsistencies between'these data sets and general equilibrium conditions are resolved using systematic adjustment procedures described in Fullerton, Shoven and Whalley (1978). Effective tax rates and parameters for equations in the model are estimated from the benchmark equilibrium data set so as to replicate the consistent 1973 data base. Economic effects of each tax policy proposal are then estimated by changing the tax rates and recalculating a simulated equilibrium.

\section{B Production}

Each industry produces a single producer good from a combination of capital services, labor services, and the outputs of other industries. Factor input decisions are assumed to be made on the basis of cost minimization, and these decisions are affected by the tax system since the relative producer prices of inputs are altered for each industry by taxes.

The use of primary factors by each industry is described by a separate C.E.S. or Cobb-Douglas production function. The model embodies a capability for preselection of functional form in addition to selection of parameter values. The intermediate use of products by industries is described by a conventional fixed coefficient input-output matrix. This matrix is derived from published 1970 input-output data for the U.S. and 
updated to 1973. No substitution between primary factors and intermediate inputs is permitted.

A number of "legal" taxation instruments are treated as production taxes and directly affect costs of industries. The corporate Income tax, corporate franchise tax, and the property tax are in combination treated as ad valorem taxes on the use of capital services. The soclal security tax, unemployment insurance, and public workman's compensation are treated as ad valorem taxes on the use of labor serivces. It 1s, of course, debatable whether these treatments are appropriate. Some recent literature argues for treating the social security tax as a benefit-related contribution and for treating the corporate income tax as a lump-sum tax or as a tax on the use of equity instruments. Our model abstracts from these controversies, but we are aware of them.

In addition to taxes on the use of primary factors, the model Includes taxes on the intermediate use of producer goods by industry and taxes on outputs of producer goods. Intermediate input taxes include the registration fees paid on wotor vehicles for business use; producer output taxes include the Federal manufacturers' excise taxes, paid by purchases for intermediate or final use. Table 2 describes the detailed treatment of all these taxes along with an outline of the entire United States tax system.

\section{C Consumption}

Within the personal sector, twelve consumer groups are identified by their family gross of tax income as reported in the 1973 Consumer Expenditure Survey data published by the U.S. Department of Labor. The number of groups are restricted in order to keep the model of manageable 


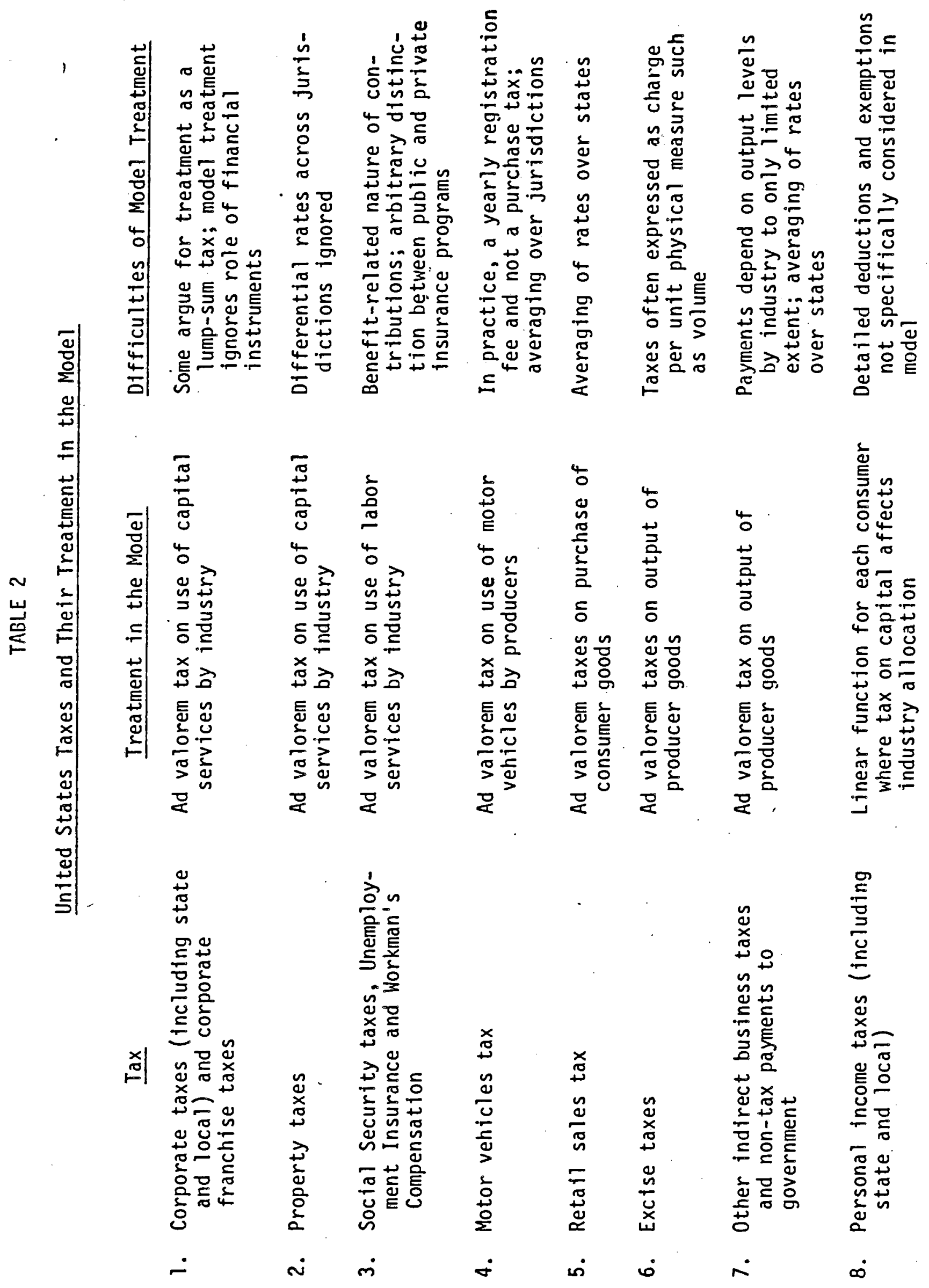


size, but other consumer groupings could be considered by the approach. Additional characteristics, such as famly size, age, marltal status of household heads, and regional location could be examined, as done by Piggott and Whalley (1977) in their model of the U.K. tax system.

The income of each consumer group in any period is determined by the ownership of labor and capital services and recelpt of transfer income, such as social security payments, from the government. Demands for the consumer goods, savings and leisure are assumed to be generated by utility maximization subject to the household budget constraint.

The nested utility function is given by

$$
U\left(u\left(\prod_{1=1}^{15} x_{i}^{\lambda}, L\right), c_{f}\right)
$$

where $u$ is a C.E.S. function determining the allocation of current expenditures between consumption goods $x_{i}$ and leisure $L$, while the purchase decisions on the $x_{i}$ are determined by a Cobb-Douglas sub-utility function as shown. The elasticity of labor supply with respect to the real after tax wage is set at t0.15 (Lewis, 1975). U is another C.E.S. function, determining the allocation of income between those current expenditures and expected future consumption $\mathrm{C}_{f}$. 'The demand for $\mathrm{C}_{\mathrm{f}}$ results in a derived demand for savings, where the elasticity of savings with respect to the real net-of-tax rate of return is taken as .4, consistent with the recent estimates by Boskin (1978).

Demands for the 19 producer goods are derived from the demands for the 16 consumer expenditure items using a "G" transition matrix. An element $g_{1 j}$ of this matrix is the amount of producer good $i$ needed to produce one unit of consumer expenditure item $j$. The distinction we make between producer and consumer goods enables us to simultaneously use national accounts data on a producer good classification and the 
and the recently released 1972-73 Consumer Expendfture Survey defined for consumer goods. The $G$ transition matrix solves the problem of distinguishing consumer demands for outputs of the trade and transportation industries from the demands for goods purchased at retail. Each consumer good requires some trade and transportation for its production. It also solves the problem of rare consumer purchases of goods such as "mining" output.

The $16^{\text {th }}$ consumer expenditure $i$ tem is savings, and the $G$ matrix permits us to treat it like other goods. We assume that the demand for savings depends upon the current rate of return on capital, given by the current price of capital services relative to the purchase price of new capital goods. ${ }^{5}$ We thus assume myopic expectations in the sense that the current rental and purchase price of capital is expected to prevail in all future periods. Actual patterns of investment good purchases are the basis for constructing the colum of the transition matrix which converts the consumer's demand for savings into demands for producer goods. This treatment assumes an equality between savings and investment. Savings of one period result in an equi-proportional increase in the capital service endowment of households where the conversion between net investment and capital service units uses a real net-of-tax rate of return of 4 percent.

Progressive personal income taxes are incorporated by a sequence of linear tax functions for each consumer. With an intercept that is usually negative and a marginal tax rate applied to all income, we can . 
replicate observed 1973 tax payments and still subject income changes to the appropriate marginal rate. State and local income taxes are modelled as "piggyback" or percentage surcharge taxes applied to the Federal levy.

Treatment of personal income taxes is complicated by the need to recognize the preferential treatment of certain types of capital income. Corporate retained earnings which are converted to capital gains have a lower present value tax liability than do eamings paid as dividends. Similarly, the extent to which capital eamings are sheltered by the unincorporated Investment Tax Credit will differ by industry. Thus, the effective personal income tax rate on capital income will differ by industry. Later we discuss the procedure used to introduce these preferential tax rates on some personal capital income, and we discuss their treatment in our modelling of the Integration plans.

Government purchases are derived from a Cobb-Douglas demand function defined over producer goods. Govemment real expenditures are assumed to equal tax receipts less transfers since the general equilibrium approach requires that the government budget must be balanced. The forelgn trade sector receives a simple treatment in order to close the model. By assuming that the net value of exports less Imports for each producer good remains constant, we can calculate the net quantity transactions at any given vector of producer prices and transform domestic demands to market demands. 
III. Corporate Financial Policies and the Lock-In Effect

There are two important aspects of corporate tax integration whlch our model does not directly consider, although we have made some efforts to examine the sensitivity of our findings to alcernative assumptions on these issues. One problem is the role of corporate financial policies and the other, is the so-called "lock-in" effect.

In recent years a number of authors (Stiglitz, 1973, 1976; King, 1974) have emphasized a view of the corporate tax as a differential tax on the various financial instruments avallable for transferring capital income from firms to individuals. Under this view there are three different ways by which capital income of corporations can be "paid" to the owners of capital: through interest payments, dividends, and retentions which are assumed to be converted into capital gains. Each of these instruments has tax and non-tax advantages and disadvantages that govern their relative use by industry. By using debt finance, interest is deductible from the coiporate tax base. This tax advantage is counteracted by the disadvantage that a heavily debt financed company has a higher probability of bankruptcy and/or takeover. Equity financing cannot avoid corporate taxation but may result in a large reduction in personal taxes if a retention policy is employed. Alternatively, though they have no tax advantage, dividends may be paid for a variety of other reasons.

For the purposes of the present paper, the important point is that with changes in tax law, firms can be expected to modify their financial policies. For example, if Plan 2 (dividend deduction from the. 
corporate tax) encourages firms to pay out all eamings in dividends, then Plan 1 (total integration) and Plan 2 are identical in their effects. Lacking good estimates of financlal policy elasticlty parameters, we examine various extreme behavioral reactions and calculate the effects of the tax change given the assumptions involved. We thus cannot claim a "true" general equilibrium treatment of corporate financial pollcies since adjustments are made to the dividend/retention ratio to estimate model equivalent tax rates before we make our general equilibrium calculation.

With the "lock-in" effect, the issue is that the deferral advantage under the existing personal and corporate tax structure gives a tax preference to retention by existing firms. New firms entering financial markets must borrow at higher interest rates than those at which existing firms can implicitly borrow through retentions. Thus, if existing firms are slower growing and less efficlent, the proper reallocation of resources to new firms need not take place.

Since we consider a general equilibrium model with constant returns to scale technology, we do not incorporate an explicit theory of individual firm behavior, and a reallocation of capital between flrms within an Industry does not affect the Industry production function. We are therefore unable to Incorporate efficiency aspects of the lock-in effect.

The resource allocation effects of corporate and personal tax integration we consider are restricted to interindustry and intertemporal distortions. Interindustry distortions enter through differential capital income tax ratés by industry, and intertemporal distortions affect savings behavior in the economy and change capital allocation over time. 


\section{Representing the Tax Integration Plans in Model Equivalent Form}

Each of the tax integration plans described in Section I 18 represented in model equivalent form for the purposes of analyzing its general equilibrium impacts. For each plan we calculate a new set of appropriate effective tax rates and use these to compute a simulated equilibrium for comparison with the data generated by the model under a no pollcy change situation.

We first calculate each industry's capital income net of corporate income tax, corporate franchise tax, and property tax. For each of the twelve consumer classes, data on marginal tax rates $\tau_{j}$ are obtained from the Treasury Department's merged tax file and a weighted average marginal tax rate $\tau$ is calculated.

For each of the nineteen industries and government, we define a fraction, $f_{1}$, which denotes the proportion of that sector's capital income which is subject to full personal income taxation. The average fraction of capital which is fully taxable by the personal income tax is denoted $\bar{f}$. The $f_{i}$ fraction differs across industries for a number of reasons, but primarily because of their different dividend and retention policies. In addition to the corporate income tax, corporate franchise tax, and property tax, we add another factor tax at the industrial level, termed the personal factor tax, and collected at rates $\tau f_{1}$ by industry

The personal income tax applied to capital income at the consumer level is given by

$$
t_{j}=\left(\tau_{j}-\tau\right) k_{j} \bar{f}, \quad j=1,12
$$


where $k_{j}$ is the capital income recelved by the $j^{\text {th }}$ consumer class. These consumer Income taxes on capltal income are both positive and negative and when aggregated over the twelve consumer classes yleld no revenue. The modelled system operates exactly as a withholding system under which each industry pays tax on $f_{1}$ of the capital used, at rate $\tau$. The consumer income taxes in expression (2) correct the tax rate for each consumer class (those with rates above $\tau$ pay more taxes while those below get refunds). Since $\tau$ is chosen as the capital welghted average of marginal tax rates, the corrections sum to zero. To calculate the $f_{i}$, we make use of data on capital income types by industry, examining corporate profits (dividends and retained earnings), net interest payments (monetary and imputed), net rent payments (including the imuted net rent from owner-occupied homes), and the return to capital used in noncorporate business. Each type of capital income is treated differently by the personal Income tax, and each has a proportion $g$ which is fully taxable by it. An industry's $f_{i}$ is the weighted average of these $g$ proportions, and each industry has different weights or amounts, of these capital Income types.

Interest and rents are fully taxed under the personal income tax. For the housing industry, imputed net rents of owner-occupied homes are not taxable. In 1973 the government's revenue loss due to the $\$ 100$ dividend exclusion from the personal Income tax was estimated at $\$ 285$ million. 6 We divide this by $\tau$ to get an estimate of nontaxable dividends, $\$ 1164$ million. Since total dividends paid 1s $\$ 24,631$ million, the proportion taxable is .96 and this figure is used as the $g$ applied to dividends, $g_{D}$. 
In the case of capital gains, Balley (1969) has shown that close to one-half of long term capital gains are realized in a relatively short perlod, while the remainder is held for varying durations, averaging perhaps 35 years or more. Weighing the advantages of exlusion and deferral in light of these observations on holding periods leads to a conclusion that about $25 \%$ of nominal capital gains are effectively included in the base of the personal income tax. Accounting for inflation, however, we calculate that $73 \%$ of real capital gains in 1973 were fully taxed at the personal level, implying .73 as our $g$ for retained eamings, $g_{\mathrm{RE}}$.

Each of the four integration plans imply different values for $f_{i}$ and for capital tax rates. Because of the government's balanced budget, however, it is important that they receive the same real tax revenue in the simulated equilibrium. Otherwlse, the change in the pattem of govemment expenditures and transfers would affect the outcome and prevent the isolation of the effects of the capital tax rate changes. Tax rates under each plan are therefore modified during computation until the resulting equilibrium tax yield allows government to make the same real purchases and give the same real transfers to consumer groups, based on Laspeyres price indices. ${ }^{7}$ Different yleld preserving taxes, both on personal income and on capital income by industry, are considered. In dynamic analyses we consider equal yield tax replacements on a period by period basis.

The modifications used in our model to represent each plan are as follows: 
Plan 1: Total Integration: Under this plan, the undesirable features of the corporate tax are removed by merging the corporate Income tax and personal income tax. Corporate taxes are eliminated from the numerator of the new capital tax rate calculation. The personal income tax is changed to tax eamings rather than fust dividends, imlying a $g_{R E}$ set to one and therefore changes in the values of the $f_{1}$ parameters. These changes 1 mply new personal factor taxes and thus new capital tax rates by industry.

Plan 2: Dividend Deduction from Corporate Tax Base: This plan's corporate income tax base is undistributed profits of corporations. It is represented in model equivalent terms for each industry by removing a portion iof the corporate tax paid from the 1973 capital taxation figures and recalculating the capital tax rate. The portion of corporate tax removed is given by the ratio of dividends to net of tax corporate profits by industry (Survey of Current Business, July, 1976). Neither the $f_{i}$ nor the personal income tax function change.

Plan 3: Dividend Deduction from Personal Income Tax Base: This plan removes the taxation of dividends from the redistributive power of the income tax system. In model equivalent terms, it is specified by considering the effect of dividend deductiblitity on the income tax functions of households. The value of the $g_{\mathrm{D}}$ proportion of dividends taxable by the personal income tax is set to zero and all $f_{f}$ are recalculated. Other adjustments are analogous to the description of Plan 1 . Plan 4: Dividend "Gross Up": This scheme gives stockholders an income tax credit of a. $15 \%$ portion of the corporate taxes paid by their firm. It is most satisfactorily modelled as a reduction in corporate 
taxes of each industry by the amount of the credit. This amount is then treated as additional dividends in the calculation of new $f_{1}$ values. The new effective tax rates then include $85 \%$ of corporate Income taxes and the new personal factor taxes. The higher dividends relative to retained eamings result in higher $f_{i}$ and $\bar{f}$ values so that consumers experience an increase in taxable capital income. The taxable nature of the credits are thus captured.

\section{Results}

Tables 3 and 4 present static efficiency and distributional results from the integration plans. Table 5 presents our calculation of dynamic effects. Although it is not a realistic policy proposal, we also report, as a basis of comparison, results from complete .. equalization of capital tax rates by industry under an equal government revenue constraint. In this case we eliminate tax discrimination on capital use among industries, use a single tax rate for all industries, and equally tax all capital income at the personal income tax level. Capital tax rates are set to a common rate providing government with enough revenue to make the same real purchases, and $f_{i}$ parameters are all reset to $\bar{f}$, the overall fraction of capital incowe which is effectively fully taxed by the personal income tax system. The resulting efficiency gains are larger than those of the four integration plans and represent the maximum possible increase in expanded national income from the elimination of interindustry capital tax distortions.

The static measures of efficiency displayed in Table 3 are the changes in national income plus leisure valued at pre and post policy change prices. We use these quantity indices rather than compensating 
TABLE 3

Change In Real Expanded* National Income under Various Assump tions

(in billions of 1973 dollars)

Tax Replacement

Equal capital tax rates on industry*t

Plan 1

Full integration with indexing

\section{Plan 1}

Full integration without indexing

Flan 2

Dividend deduction from corporate income tax

Plan 2

With extreme behavior assumption

Plan 3

Dividend deduction from personal income tax

Plan 3

With extreme behavior assumption

Plan 4 Dividend Gross-up

\section{Price Index}

Paasche (lower bound)

Laspeyres (upper bound)

Geometric mean.

Paasche (lower bound)

Laspeyres (upper bound)

Geometric mean

Paasche (lower bound)

Laspeyres (upper bound)

Geometric mean

Paasche (lower bound)

Laspeyres (upper bound)

Geometric mean

Paasche (lower bound)

Laspeyres (upper bound)

Geometric mean

Paasche (lower bound)

Laspeyres (upper bound)

Geometric mean

Paasche (lower bound)

Laspeyres (upper bound)

Geometric mean

Paasche (lower bound)

Laspeyres (upper bound)

Geometric mean
Types of Scaling to Preserve Tax Yield

\section{Scale Common Rate}

7.377

10.220

8.682

Lump-sum Multiplicative

10.029
12.363
11.135

5.282

7.292

6.206

$\frac{\text { Additive }}{5.448}$

7.446

6.369

$\begin{array}{rll}8.883 & 5.120 & 5.223 \\ 10.628 & 6.646 & 6.748 \\ 9.716 & 5.833 & 5.936\end{array}$

4.864

2.713

3.253

5.268

3.021

3.598

5.061

2.862

3.421

10.236

12.716

11.408

5.284

5.470

7.418

7.588

6.260

6.442

3. 720

3.964

2.440

2.653

2.500

3.840

2.544

2.706

2.600

5.611

6.367

2.992

3.151

5.977

3.642

3.777

3. 301

3.449
3.590
3. 748
3.668

2.681

2. 820

2. 749

2.712

2.850

2.780

\footnotetext{
* This incorporates the change in the valuation of leisure through induced variations in labor supply. Additive and multiplicative scaling refer to the marginal tax rates of the personal income tax system.

$\star \star$

These results are for conplete equalization of capital tax rates by industry (Including property tax, corporate franchise tax, investment tax credit, etc.) They are presented for comarison purposes.
} 
or equivalent variations because the utility contribution of savings may be inaccurately assessed by consumers due to their myopic expectations. For the dynamic welfare effects shown in Table 5 we evaluate the Instantaneous utility function (u) from equation (1). We report the sum of present value analogues of compensating variations using these utility functions. This measure reflects the amount in 1973 dollars which would have to be given to the twelve consumer groups to leave them indifferent between the present tax system' and the tax integration plan.

Results in Table 3 indicate that the efficiency gain from equalizing capital taxes by industry is about $\$ 8.7$ billion per year in 1973 dollars. The single-period change in the real after-tax income of each of the twelve consumer classes is presented in Table $4 .^{8}$ The efficiency gain turns out to be distributed in such a way that every group experiences an increase in real income, and thus a Pareto improvement occurs. 9 Dynamic gains in this case (Table 5) are $\$ 340$ billion, which is about 0.8 percent of the discounted present value of the future U.S. income stream after correction for population growth. We have calculated but do not report percentage changes in price and in output by industry for this replacement and for each tax plan. Other information on new capital and labor use by industry, taxes paid, and all types of demands are available for each tax replacement. 10 The findings for each of the integration plans are as follows:

Plan 1: Total Integration: This plan removes only part of industrial discrimination in the taxation of capital income because property taxes remain as differential capital taxes by industry. Intertemporal distortion is substantially reduced. We consider equal yield tax replacements, 


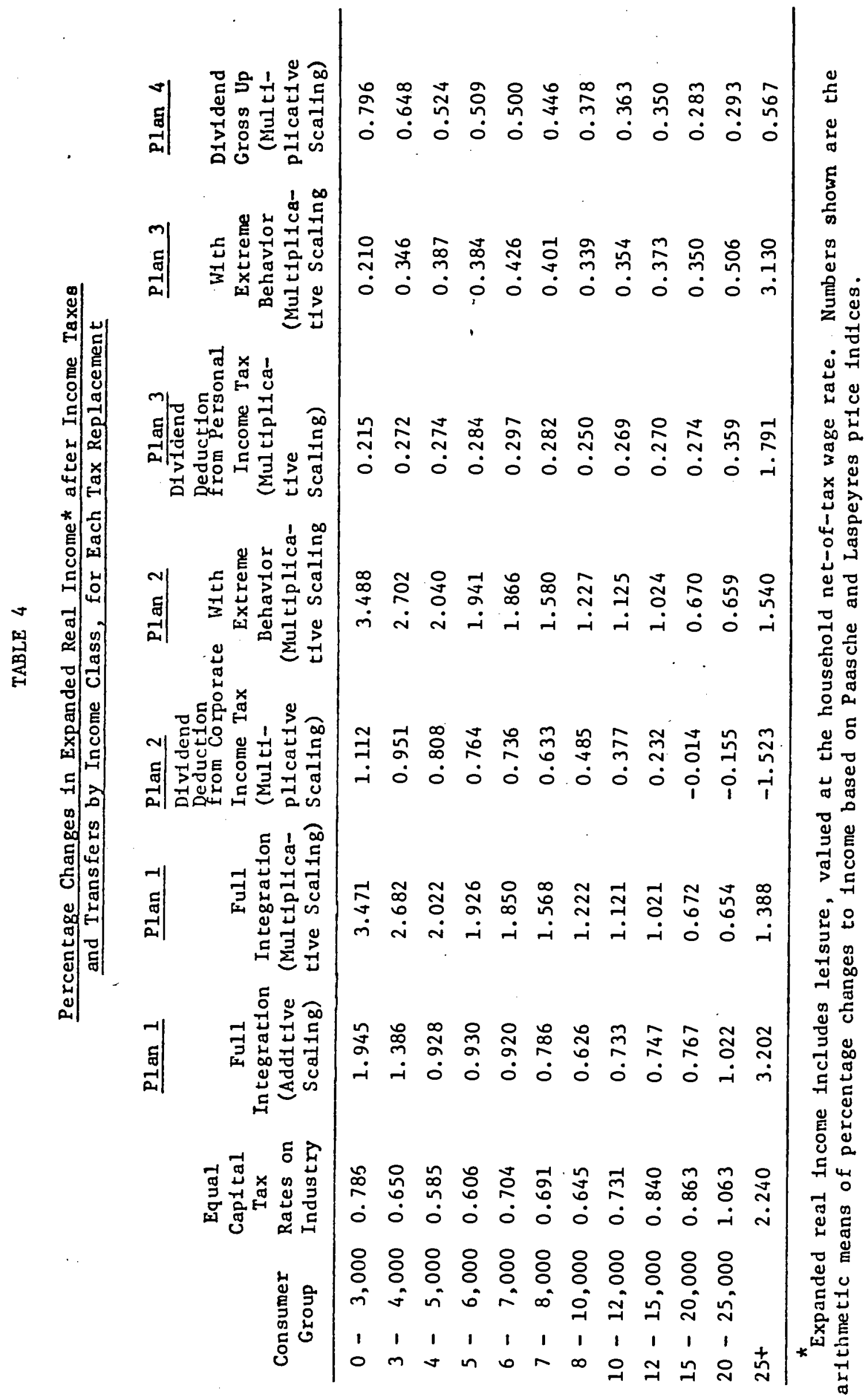


TABLE 5

Dynamic Welfare Effects in Present Value of Compensating Variations over Time*

(in billions of 1973 dollars)

Tax Replacement

Equal capital tax rates on industry

Plan 1

Full integration

with indexing

Plan 1

Full integration

without indexing

P1an 2

Dividend deduction from

corporate income tax

Plan 2

With extreme behavior

assumption

P1an 3

Dividend deduction from

personal income tax

P1an 3

With extreme behavior

assumption
Types of Scaling to Preserve Tax Yield

\section{Scale Common Rate}

339.273

$(.808) * * *$

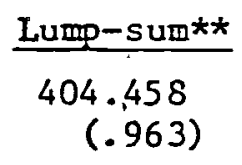

Multiplicative**

179.977

(.429)

Additive**

229.966

(.548)

\author{
350.164
}

(.834)

175.094

(.417)

213.588

(.509)

195.666

113.810

(.271)

131.327

(.313)

(.466)

$$
\text { (.271) }
$$

179.858

(.428)

232. 322

(.553)

(.987)

175.449
$(.418)$

113.413

(.270)

121.736

(.290)
284.630
(.678)

158.464

(.337)

185.367

(.441)

Plan 4

Dividend

$\frac{\text { Gross-up }}{\star}$

139.558

(.332)

96.305

(.229)

105.335

(.251)

These measures involve calculating a sequence of momentary equilibria through time with increment of the capital and labor service endowments of the economy through savings and population growth. We consider five equilibria at 10 year periods with an appropriate treatment of the terminal conditions. The dynamic compensating variations are analogues of static concepts applied to the consumption sequence over time assuming the first period discount factor is unchanged.

$\star \star *$ $\star \star \star *$

These are explained in the text.

The numbers in parentheses represent the gain as a percentage of the present discounted value of welfare (consumption plus leisure) in the base squence. This value is $\$ 42$ trillion for all comparisons, and accounts for only a population the size of that in 1973. 
as described earlier, such that taxes are scaled up to meet tax revenues from the corresponding period of the previous tax reglme. We consider lump-sum adjustments to income taxes along with additive and multiplicative scaling of marginal income tax rates. Interindustry discrimination is reduced enough to provide a $\$ 6$ billion static welfare gain in'each year (in 1973 dollars) for the cases with either multiplicative or additive scaling and inflation indexation of capital gains taxes. Without this price level correction, the efficiency gains are slightly less. Dynamic gains are sensitive to the replacement yield preserving tax considered. With lump-sum replacement a gain of $\$ 404$ billion occurs, and with multiplicative scaling a gain of $\$ 180$ billion occurs. These figures are to be compared with a $\$ 42$ trillion discounted present value of the future income stream for the U.S. economy under the present tax system (after correction for population growth, in 1973 prices). The sensitivity of these dynamic results to the replacement tax can be explained by the positive correlation between income and proportion of income saved. Since multiplicative scaling collects more tax revenue from high-income groups, it creates a greater distortion in their intertemporal choices.

Static equity effects provide progressive gains to income brackets, shown in Table 4, with every class enjoying increased real income. The importance of the structure of the replacement yield preserving tax is apparent from Table 4, multiplicative scaling helping lower-income groups substantially more. ${ }^{11}$.

We do not need to consider changes in financial policies under this plan. With full integration, all forms of capital income are taxed 
1denticaliy. Since the tax does not depend on whether capital income is paid in interest, dividends, or retalned, a change in either the debt/equity or dividend/retention ratio will not alter the new effective tax rates or the new $f_{1}$ for the revised equilibrium calculation. The resulting solution would thus be the same even if the ratios changed.

Plan 2: Dividend Deduction from Corporate Income Tax Base: Here dividends are treated like interest for tax purposes, and we first assume that corporations continue to retain the same portion of income. The reduction of the corporate income tax base causes some levelling of capital tax rates and a resulting $\$ 3$ billion increase in yearly national income. Dynamic gains under multiplicative scaling of tax rates are $\$ 114$ billion. Under a lump-sum replacement, dynamic gains are \$196 billion. The reduced spread of dynamic results is due to the smaller revenue loss associated with PIan 2: there is less distortion of intertemporal choice through scaling. The static distributional impacts are disadvantageous to the higher-income groups, reflecting the fact that less income is taxed at the flat corporate rate and more at the progressive personal rates. Under our "standard" treatment of Plan'2, dividend/retention ratio is assumed constant even though there does exist an incentive to replace retained eamings with now non-taxed dividends. For this reason we also consider the extreme case where all corporate earnings are distributed. The corporate income tax would thus be effectively eliminated, and $f_{i}$ calculations would proceed on the assumption that all corporate earnings get multiplied by the higher .96 for $g_{D}$. The static gain for such a $t a x$ replacement is around $\$ 6$ billion per year, the same as under Plan $I$; the dynamic gains are also comparable. These velfare gains are substantially above the fixed-behavior estimate because corporate decision makers have, 
In effect, reduced the distortion of the corporate income tax with its differing effective capital tax rates. The static distributional results of the Plan 2 extreme-behavior case show more progressive gains among consumers .

Plan 3: Dividend Deduction from Personal Income Tax Base: The reduced tax on dividends again implies lower tax rates on heavily incorporated industries and a leveliling of all rates in general. This occurs through the lower $f_{i}$ for dividend paying industrles. Static welfare gains are about $\$ 2$ billion per year; dynamic gains under multiplicative scallng are about the same as Plan 2 , at $\$ 113$ billion, but under 1 umpsum replacement are lower than Plan 2; at $\$ 175$ billion. The multiplicative results reflect the importance of the deduction from the upwardly scaled income tax. As might be expected, Table 4 shows that Plan 3 has more regressive effects than the second plan, since dividend income is all taxed at the corporate rates instead of being taxed at progressive personal tax rates.

Under extreme financial policy behavior, where firms no longer retain earnings, both the static and dynamic gains are somewhat larger. The corporate tax remains the same, but new $f_{1}$ include all corporate earnings as dividends with a $g_{D}$ of zero. Less corporate income Is subject to the personal income tax. The difference between results with and without the extreme-behavior assumption is less than for Plan 2 because the personal income tax deduction does less to elibinate interindustry discrimination than does the corporate Income tax deduction of dividends. Equity effects are still regressive for the extreme-behavior case: 
Plan 4: DIvldend "Gross Up": All plans that decrease the corporate income tax only on dividends can be termed partial integration plans. The fourth plan, because it reduces only part of the tax on dividends, fht be called a partial-partial plan. The tax system is changed to a lesser degree, and the static welfare gain is small, at $\$ 2.8$ billion per year. Dynamic gains under multiplicative scaling are $\$ 96$ billion, under additive scáling are $\$ 105$ billion, and under a lumpsum replacement are $\$ 140$ billion. ${ }^{12}$ Equity effects are closer to proportional than under Plan 1, but with smaller gains.

Perhaps the most interesting of our results for all the integration plans are the dymamic results which suggest significant potential gains from corporate tax integration, provided replacement taxes do not excessively interfer with intertemporal consumption choice. There appears to be a trade-off between achieving progressive or proportional income gains through multiplicative scaling and maximizing the dynamic efficiency. gain: the largest intertemoral gain could be secured by taxing the poor who do not save.

\section{Conclusion}

In this paper we have analyzed four alternative plans for corporate and personal income tax integration in the U.S. by using a recently constructed medium-scale general equilibrium model of the U.S. economy and tax system. The paper includes a brief discussion of the model and 1 ts use of data, in addition to outlining characteristics of the integration plans and their representation in model equivalent form.

Total integration of personal and corporate income taxes is shown to yield static efficiency galns of $\$ 6$ billion per year using 1973 data; 
and the present value dynamic gains range from $\$ 414$ billion to $\$ 96$ billion in 1973 prices, depending on the yield preserving tax. Dividend deductibility from either the corporate income tax or the personal income tax results in a static efficiency increase of slightly less than half of the gains from full integration. A 15 percent dividend gross-up scheme yields somewhat less than dividend deduction from the corporate tax but a little more than deduction from the personal income tax. The distributional impacts vary among plans; full integration with a multiplicative scaling of marginal income tax rates to preserve tax yields is shown to imply a progressive change in the distribution of real income even though every class is better off. Dividend deductibility from the personal income tax is shown to have a beneficial impact slightly more advantageous to high-income groups, while dividend deductibility from the corporate income tax redistributes from high to low income groups. The dividend gross-up plan is roughly proportional. In the sensitivity of dynamic gains to the yield preserving tax we find an interesting result. It suggests that the potential gains under integration from removal of intertemporal distortions would be significantly reduced if marginal income tax rates are raised, particularly if the higher-income groups, who are also larger savers, face larger tax rate increases. 


\section{REFERENCES}

M. J. Bailey, "Capital Prices and Income Taxation." In A. C. Harberger and M. J. Bailey (eds.), The Taxation of Income from Capital. Washington, D. C.: The Brookings Institution, 1969.

M. J. Boskin, "Taxation, Saving and the Rate of Interest," J. Polit. Econ., 1978, 86, no. 2; part 2, pp. S3-S27.

D. Fullerton, A. T. King, J. B. Shoven, and J. Whalley, "Corporate and Personal Tax Integration in the U.S.: Some Preliminary Findings from a General Equilibrium Analysis." In R. Haveman and K. Hollenbeck (eds.), Microeconomic Simulation. Madison, Wisconsin, Institute for Research on Poverty, 1979.

D. Fullerton, J. B. Shoven, and J. Thalley, "General Equilibrium Analysis of U.S. Taxation Policy," 1978 Compendium of Tax Research, Washington, D. C.: Office of Tax Analysis, U. S. Treasury Department, 1978.

M. A. King, "Taxation and the Cost of Capital," Rev. of Econ. Studies, 1974, XII, no. 1, pp. 21-36.

H. G. Lewis, "The Ecomomics of Time and Labor Supply," The Amer. Econ." Rev., $1975, \underline{L X V}$, no. 2, pp. 29-34.

J. R. Piggott and J. Whalley, "General Equilịbrium Investigation of U.K. Tax Subsidy Policy: A Progress Report." In M. J. Artis and A. R. Nobay (eds.), Studies in Modern Economic Analysis. Oxford: B. Blackwe11, 1977 .

J. B. Shoven and J. Whalley, "Equal Yield Tax Alternatives: General Equilibrium Computational Techniques," J. of Public Econ., $1977, \underline{8}, \mathrm{pp} .211-224$. 
J. E. Stiglitz, "Taxation, Corporate Financial Policy and the Cost of Capital," J. of Public Econ., 1973, 2, no. 1, Pp. 1-34. , "The Corporation Tax," J. of Public Econ., 1976, 5, no. 3, Pp. 303-311.

J. Whalley, "A General Equilibrium Assessment of the 1973 U.K. Tax Changes," Economica, May 1975, Pp. 139-161. 


\section{FOOTNOTES}

*Don Fullerton, Princeton University; A. Thomas King, Federal Home

Loan Bank Board; John B. Shoven, Stanford University and National

Bureau of Economic Research, and John Whalley, Universtty of Western ontario.

1. The competitive model implies net of tax rates of return on capital are equalized across industry. In a situation where capital tax rates vary by industry, this equalization requires that the gross marginal productivity of capital differ among the industries. The efficiency gain accomplished by reducing the differential capital $\operatorname{tax}$ rates is due to the reallocation of capital towards industries where it is more productive.

2. A 15 percent credit was often mentioned and is modelled here. A further possibility discussed was that differential credits might be given depending on the industry in which a company operates; this is not modelled.

3. Future extensions of this approach could disaggregate labor into skill types since these might have different rates of substitution for capital. Similarly, capital could eventually be broken down into land, equipment and structures, or some other useful definitions.

4. Earler data sets of this type for the U.K. have been used by Whalley (1975) and Piggott and Whalley (1977). 
5. In order to capture the tax exempt nature of saving through pensions, Reogh plans, Individual Retirement Accounts, and life insurance, we model a $30 \%$ savings subsidy within the income tax framework. This proportion reflects data from Flow of Funds accounts. Another $20 \%$ of savings through owner occupied housing is also taxed on an expenditure tax basis, indicating that the U.S. Is approximately half-way between Income and expenditure taxation. Housing tax preferences are also captured by the model as discussed below.

6. 1976 Tax Expenditures, U.S. Congress.

7. Operation of the equal yield calculation is discussed in Shoven and Whalley (1977).

8. Because of the general equilibrium nature of these calculations, both sources and uses effects are included in the Table 4 distributional results. The rental price of capital rises in the simulated equilibrium. Low-income consumers tend to purchase outputs of lightly-taxed, capital-intensive industries like housing, agriculture, and petroleum. Thus the uses side of income has some regressive effects. On the sources side, note that the capital/labor ratio of income from our data is bowl-shaped over income groups. This is largely due to their age structure. Since our model calculates a long-run equilibrium, where homogeneous capital is reallocated among industries, the new higher return to capital is earned by all capital owners regardless of their original portfolio. The higher price of capital causes bowl-shaped gains on the sources side of income.

9. Although the simulated equilibrium is a Pareto improvement over the benchmark 1973 equilibrium, we have said nothing about the possible paths between the two. Short-run losses and transition costs should 
be considered before enacting such a change. Our model is essentially comparative static and does not measure these disequilibria or temporary influences.

10. This addicional information is avallable from the authors on request.

11. The U-shaped gains of the additive replacement can be explained by the higher return to capital in the simulated equilibrium. The capital/labor ratio of income is greatest for the low-income (retired) individuals and again for high-income individuals.

12. Here, again, the spread between the dynamic welfare gains is less than that of full integration because this plan involves smaller revenue loss than full integration. Multiplicative scaling makes up most revenue from high-income, high-saving consumers, and it thus reduces future capital stocks and incomes. The dynamic 1 umpsum and additive cases show that the dividend gross-up does substantially less to improve interindustry resource allocation. than other plans. 